\title{
PREDICTING THE EVOLUTION OF COASTAL LOUISIANA'S BARRIER ISLANDS
}

\author{
Michael Poff, Coastal Engineering Consultants, Inc., mpoff@cecifl.com \\ Vadim Alymov, Coastal Engineering Consultants, Inc., valymov@cecifl.com
}

\section{INTRODUCTION}

The Louisiana barrier islands are one of the outcomes of the Mississippi River outlet changing over the past several thousand years. It is the natural shifts in the river channel alignment interacting with the combination of anthropogenic impacts, sediment transport, and significant storm events that drive barrier island formation and subsequent erosion and migration. Predicting the evolution of Louisiana's barrier islands is a critical component of Louisiana's Coastal Protection and Restoration Authority (CPRA) program for restoring and sustaining their barrier islands. Both empirical and numerical modeling approaches, as well as hybrid modeling approaches, have been utilized for predicting morphologic changes over time. These predictions have been employed for the development of single-island restoration projects, and for the long-term basin-scale modeling completed for the 2017 Coastal Master Plan (CPRA, 2017) for which Coastal Engineering Consultants served on the barrier island modeling team.

\section{KEY PHYSICAL PROCESSES, FORCING} FUNCTIONS, AND GEOMORPHIC FORMS

Physical processes, forcing functions, and geomorphic forms that influence the morphologic changes include longshore sediment transport, cross-shore sediment transport, breaching, inlets and bays, post-storm recovery, subsidence, and eustatic sea level rise. The two key processes that dominate barrier island evolution are alongshore and cross-shore sediment transport.

\section{LONGSHORE TRANSPORT}

Longshore transport is defined as the movement of sediment parallel to the shoreline caused by waves approaching the shoreline obliquely and/or longshore currents. Empirical approaches to compute shoreface erosion from longshore transport include the application of historic erosion rates and application of single-line theory transport formulations, e.g., the Coastal Engineering Research Center (CERC) (1984) formulation. Numerical approaches have included process-based morphological area models such as Delft3D (Deltares, 2011).

\section{CROSS-SHORE TRANSPORT}

Cross-shore sediment transport is defined as the movement of sediment perpendicular to the shoreline primarily caused by storm events noting profile shaping and retreat can also occur in quiescent periods. Empirical approaches to compute overwash and island migration include application of post-storm observations and measurements. Numerical approaches have included one-dimensional models that predict crossshore responses to storms, e.g., SBEACH (Larson and Kraus, 1989) and process-based models, e.g., Delft3D.

\section{HYBRID MODELS}

Due to the large spatial and temporal scales of the landscape models implemented for the 2017 Coastal Master Plan, a hybrid modeling approach was developed to account for the key processes. For longshore transport, process-based modeling of nearshore wave transformation utilizing the SWAN model (Booij et al., 1996) calibrated to published longshore transport rates and the CERC transport formulation were employed. For cross-shore transport, SBEACH was utilized to develop look up tables to represent the range of possible profile responses to select storms (CPRA, 2017). Island morphologic responses to the rest of the key processes, forcing functions and geomorphic forms were predicted through application of empirical methods.

\section{CASE STUDIES}

The process-based modeling approach utilized by Coastal Engineering Consultants for the design of a systemwide multi-island restoration project (Figure 1) and the hybrid modeling approach employed for the 2017 Coastal Master Plan will be presented.

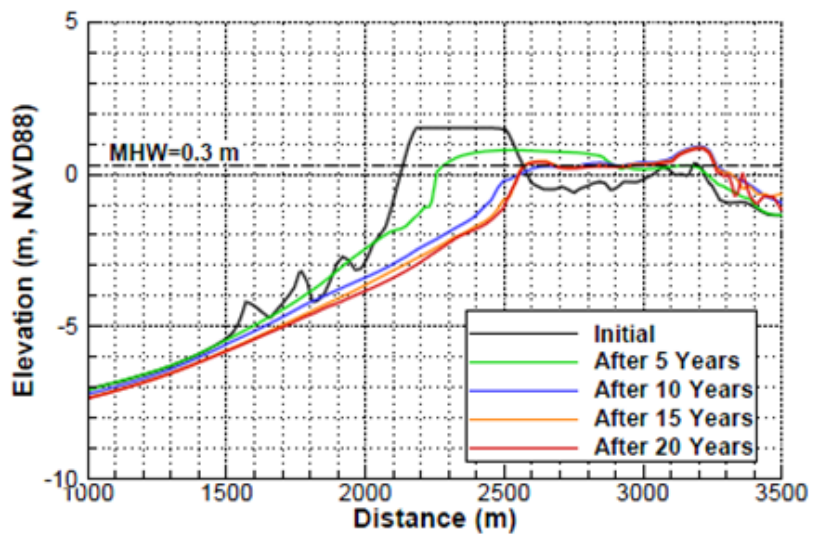

Figure 1 - Modeled Profile Transformation of Terrebonne Basin Island Beach and Dune Restoration

\section{CONCLUSION}

Developing and improving the techniques to predict barrier island evolution benefits decision makers for developing individual island restoration strategies and the basin-scale long-term master plan. Comparing island evolution trends "with" and "without" restoration informs the engineering and scientific community on how to maximize project performance.

\section{REFERENCES}

Booij, Holthuijsen, and Ris (1996): The SWAN wave model for shallow water, Proceedings of the 25th International Conference on Coastal Engineering.

Coastal Engineering Research Center (1984): Shore Protection Manual. U.S. Army Corps of Engineers.

Coastal Protection and Restoration Authority of Louisiana (2017): Louisiana's Comprehensive Master Plan for a Sustainable Coast.

Deltares (2011): Delft3D-FLOW Simulation of MultiDimensional Hydrodynamic Flows and Transport Phenomena, Including Sediments, User Manual.

Larson and Kraus (1989): SBEACH: Numerical Model for Simulating Storm-Induced Beach Change, Report 1. 